is much less restrictive than the original resolutions. And opponents of the research are pleased that the vote has established the principle of community control over scientific research.

There is, however, considerable unease within the scientific community, and with good reason. The council meeting secured a precarious ceasefire, which could easily erupt into renewed hostilities. An important factor in what happens next will be the work of the experimentation review board. Its terms of reference are broad and hazy, and its members are yet to be appointed. One potential member is George Wald, who was asked by Vellucci last week whether he would serve if asked and replied that he would be "happy and honoured to do so". Vellucci said after the meeting that the board would contain both supporters and opponents of the research and that some city residents would also be included. If necessary, he said, he would lock them all into a room and not let them out until they have come to an agreement.
Creation of the board has at least taken the council out of its uncomfortable position in the middle of the dispute. But if the board has not reached agreement at the end of three months, the council will be thrown right back in and there would then be a possibility that the moratorium would be lengthened and, perhaps, broadened. Alternatively, if the board vigorously pursues its mandate to look into all laboratory work in Cambridge, there is a danger that it could turn into a public witch hunt. "We will be keeping our fingers crossed in the next three months," says Richard Leahy, a dean in the Faculty of Arts and Sciences.

On the other hand, creation of the review board at least establishes a long-needed channel of communication between the university scientists and the city. It could provide an important vehicle for informing and educating the people of Cambridge about recombinant DNA research and about the process which led to adoption of the NIH guidelines. It is conceivable that it could even help smooth some of the causes of town-gown friction.

Another possibility which is clearly worrying people far removed from Cambridge is that similar clashes could erupt in other cities. In that respect, Vellucci has been active. Last month he attended a meeting of the United States Conference of Mayors armed with a resolution stating that "no university or institution may begin recombinant DNA experiments without first notifying the mayor of the city or town in which the experimentation will take place. Thereupon, the mayor and legislative body shall call a public hearing so that the public may be an active participant in the decision-making process". The resolution was referred to a committee for consideration, and Vellucci said last week that he intends to press the matter at future meetings.

It is possible that the dispute in Cambridge will now quietly die away. But with so many articulate and politically motivated scientists opposed to the research there, the prospects at this stage are far from certain. The next few months will be critical.

\section{JRC programme awaits approval}

The Commission of the EEC has circulated final proposals for the next multiannual research programme of the Joint Research Centre. These now await ratification from the Council of Ministers. Chris Sherwell reports

THE multiannual research programme of the European Community's Joint Research Centre (JRC) for the four years beginning in January 1977, the final detailed proposals for which were submitted by the Commission to the Council of Ministers some two weeks ahead of the Council's May 24 meeting, may not be approved before September, even though preliminary discussions of the overall framework for the Community's 1977 budget are due to start later this month.

The Council decided at the May meeting to consult both the European Parliament and the Economic and Social Committee, even though there is a clear need for the JRC's budgetary requirements for 1977 to be entered into the budget for the coming financial year. The European Parliament is being urged to deliver its opinion no later than its part-session in September, which is about the time when the Finance Ministers are expected to be reaching more concrete budgetary decisions.

The Commission's proposed programme represents the outcome of many months of behind-the-scenes deliberation, including broad consultation with research and administrative staff. Last October the Commission sent to the Council its "Overall Concept" for the programme, setting out guidelines for the JRC's future role, and this the Council discussed at an inconclusive December meeting along with a document on a joint research and development policy. Other discussions took place in February, and the General Advisory Committee considered the draft programme in March and the Scientific and Technical Committee considered it in April.

The Commission has already stated that in framing the new programme it took into account "criticism made in where" that the JRC "had engaged in too many 'half-baked' projects which it had not the resources to complete" -criticism which arose, it said, "in part from the failure of the member effective guidelines".

Details of the final proposals now under consideration are shown in the accompanying table, but do not include the installation of the JET fusion project, which the Commission wants at Ispra, since a decision on the matter is still awaited.

In its final proposals the Commission points out, some would say rather obviously, that among the the European Parliament and elsestates to provide the Centre with guiding principles of the programme, primary consideration was given to the Community's interests in science and technology. From its discussion of these principles and of the JRC's role, however, a few important points emerge, namely, the priority being accorded to energy and environment questions, the stress on a Community public service role for the JRC (that is, making equipment, know-how, products and services available), and the concentration of activities and research potential on a small number of projects. There is also emphasis on the "rolling plan" character of the proposed programme, and on management and staff aspects.

The three-year rolling system, proposed in order to allow a greater degree of adaptability, is quite simple. The four-year programme would be submitted during the third year, when the Council would adopt a new fouryear programme in which the last year of the initial programme would become the first year of the new programme. The new programme would itself be submitted for revision during its third year, when a decision would be taken on the following programme. In the absence of decisions, current programmes would be continued according to the Council's original decisions.

Regarding the financial requirement over the forthcoming four-year period of 374.4 million units of account ( $£ 156$ million), the Commission says the pattern of investment expenditure envisaged means in practice that it will not 
be divided into equal annual parts; rather, it is expected that the annual budgets will actually show a decrease over the four years.

The impact of proposals regarding researchers attached to the JRC has statistical consequences to which the Commission draws attention. Its concern over their mobility is reflected in the proposal, approved broadly by the European Parliament and still under examination by the Council (the Commission urges that it be adopted as soon as possible), for a different manner of payment; a new "research staff" concept is also adopted which stretches beyond existing "first line staff" to include associated technical support staff.

Thus, as the document goes on to point out, if the "research staff" number and programme expenditure are taken together as a measure of the distribution of effort within the JRC, programmes I, II and III (which can be broadly classed as "nuclear safety") take up $48 \%$ of the total, future

The Multiannual Research Programme of the JRC proposed by the European Commission

Programme

Projects in programme

Reliability and risk assessment; Light water reactors loss of coolant accidents; Liquid metal fast breeder subassembly thermohydraulics; Fuel coolant interactions and core melt-down; Dynamic structure loading and response; Structural failure prevention

II Plutonium fuels and actinide research

Utilisation limits on plutonium fuels; Plutonium and actinide aspects of the safety of the nuclear fuel cycle; Actinide research

III Management of nuclear materials an radioactive waste

Evaluation of long term hazards of radioactive waste disposal; Chemical separation and nuclear transmutation of actinides; Fuel materials management; Reactor component decontamination studies

IV Solar energy

V Hydrogen

Thermal conversion in housing; construction of European installation to simulate solar irradiation; orientative research on advanced applications of solar energy

Thermochemical processes for water decomposition; heat source coupling

VI Conceptual studies on Participation in conceptual study thermonuclear fusion of an experimental power reactor in connection with Euratom-CNEN association at Frascati (blanket neutronics, heat transfer and energy conversion systems etc)

VII High temperature materials

Industrial needs; effect of operational environment on mechanical properties; failure modes in applications; relationship of structure and properties

VIII Environment and resources

Atmosphere; water; chemicals; renewable (agricultural) resources

IX Measurements, standards and reference techniques

Measurement of nuclear data; nuclear and non-nuclear reference methods and techniques; scientific support to the services of the Commission and Secretariat of Community Bureau of Reference

$\mathrm{X}$ Services and support Exploitation of high flux reactor; activities

informatics; education and

\section{Total}

Personnel

Research Staff

440

239

209

161

57

7
training; safeguards; technical evaluations in support to the Commission

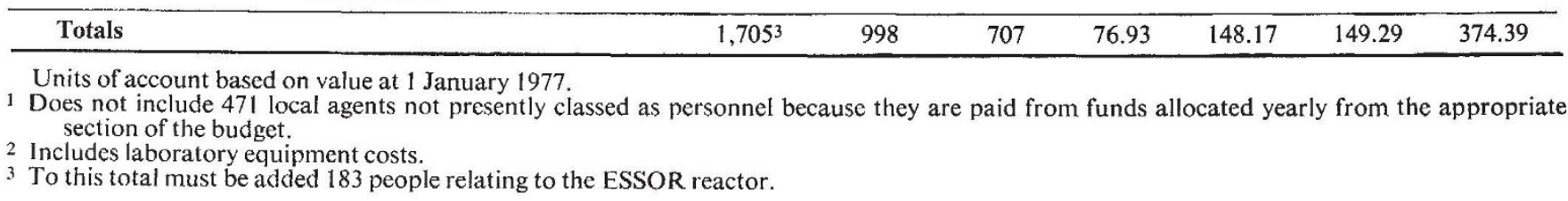


energies (programmes IV, V, VI and VII) take up $12 \%$, environment and resources $10 \%$, reference work $17 \%$ and support $13 \%$.

This as the Commission says, means that effectively $70 \%$ of the JRC's effort will be devoted to "energy and the environment", with much of the effort in energy concerned with nuclear safety. The Commission points out elsewhere that the proposals also achieve a better $(60: 40)$ balance in the ratio of payroll costs $(214.6 \mathrm{muc})$ to operating expenses (159.8 muc).

The new programme, provided it is adopted in time, will follow on the existing multiannual programme, adopted in 1973 , being carried out in the four JRC establishments at Geel (Belgium), Ispra (Italy), Karlsruhe (West Germany), and Petten (Holland). The large body of the work will be at Ispra. Karlsruhe will take the lead in plutonium fuels and actinide research, Petten will work on high temperature materials, and Geel will coordinate the work on reference methods.

\section{BRAZIL}

- Brazilian engineers have now succeeded in modifying an automobile engine to run on pure alcohol. This could be significant in solving energy problems here, in view of the fact that Brazil imports more than $80 \%$ of the crude oil it uses for making petrol. The experimental engine, installed in a Brazilian-made Dodge sedan and demonstrated to government officials in Brasilia, achieved 23 miles per gallon-roughly the same as that model gets with a gasoline engine-and had no trouble keeping up a steady 55 miles per hour in a highway test. The alcohol engine also released far fewer pollutants in its exhaust than a standard engine. Brazil's commerce and industry minister, Severo Gomes, was impressed by the demonstration. He said that if an alcohol engine is produced in volume here, it will be put first in buses and taxis in big cities.

Brazil has the potential to be selfsufficient in alcohol fuel. It is the world's biggest cane sugar grower (sugar is the country's current prime source of alcohol), and it has unmeasured quantities of cassava, a plant whose root provides a basic food for millions of poor farmers and which local scientists say can also be made to yield commercially usable alcohol.

The government's oil refining monopoly, Petrobras, currently dilutes its gasoline by $20 \%$ with alcohol, to make imported crude oil stretch further.

- Sao Paulo, Brazil's biggest metropolis (city population: 7 million; including the suburbs: 10 million), also has South America's biggest air pollution problem. A combination of thermal inversion, industrial smoke and automobile exhaust gives Sao Paulo the look of London in the days before anti-pollution measures went into effect in Britain. The air quality in Sao Paulo is often so bad that department stores take out newspaper advertisements for filter masks.

But now local health officials have persuaded the mayor's office and the police to cooperate in a plan called "Operation Winter", which will be put into effect on badly polluted days during the South American winter
(June-September), when pollutiontrapping temperature inversion is at its worst in Sao Paulo. The operation has three stages: a warning level, an alert level, and an emergency level when local authorities will prohibit the use of petrol and diesel-powered

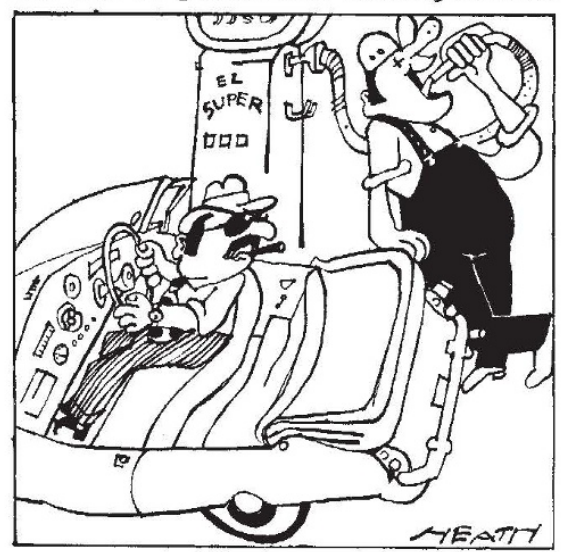

vehicles, shut down all factories and prohibit all burning.

This type of action has never before been contemplated in Brazil, where the official line has been that pollution is the price a developing country must pay if it wishes to progress since time spent on its control is time wasted.

- Brazil has been complimented for its progressive laws protecting wildlife and, at the same time, criticised for its inability to enforce them. This is especially true in the vast, underpopulated Amazon region, where it is virtually impossible to control illegal trafficking of protected species of birds and animals.

Occasionally, though, the authorities get results. Police in Rio followed up a recent tip that dogs and cats in a residential neighbourhood had been mysteriously disappearing, and this led them to what apparently is a large-scale contraband ring for exporting Brazilian Amazon creatures such as monkeys. parrots, parakeets, tucans and canaries.

Four persons were arrested on suspicion of running an illegal animal trade to Europe, North America and Japan. The police found hundreds of caged birds and monkeys awaiting shipment out of the country. They also found many dead animals which did not survive flights from the
Amazon city of Belem to Rio. The operators of the smuggling ring apparently had been using local dogs and cats to make food for the captured Amazon animals.

In similar actions, police in Sao Paulo and Fortaleza recently broke up illegal trafficking in songbirds which are protected by wildlife laws. There is a big local demand for many varieties of these popular birds in Brazil, and breeders and sellers seem willing to run the risks to make a profit.

- In another instance of Brazil's finally applying a law that had seemingly existed only on paper before, naval authorities in the northeastern city of Salvador slapped a fine equivalent to $\$ 25,000$ on a local titanium company after a pipe broke at its factory and sent sulphuric acid and ferrous sulphate spilling on to Atlantic Ocean beaches, leaving a brownish stain several miles long in the water. Among the beaches hit was Arembepe, which often is played up in tourist brochures as a Brazilian "unpolluted paradise".

Brazil's biggest lagoon, Lagoa dos Patos, which is near the country's far southern tip, is becoming so polluted that fish and shrimp are dying en masse, and even some farm animals have died of poisoning after drinking water from it. Scientists at the Rio Grande do Sul State Center for Toxicological Studies are not sure, but they think the cause is a sharp increase in the use of DDT and other insecticides on nearby farms. Soybean and wheat production in Rio Grande do Sul have gone up dramatically in recent years, and farmers there traditionally have used large amounts of pesticides.

Fishermen around Lagoa dos Patos say their annual catch in the 3,800square-mile lagoon is going down steadily. And bird watchers in the region have noticed that the oncecommon marsh cardinal no longer is seen and that the Patagonian duck does not stop at the lagoon any more on its winter flight north from Argentina.

Bruce Handler Rio de Janeiro 